\title{
MODELLING OF THE AEROSPACE STRUCTURE DEMONSTRATOR SUBCOMPONENT
}

\author{
Piotr Bajurko \\ Centrum Technologii Kompozytowych, Instytut Lotnictwa, \\ al. Krakowska 110/114, 02-256 Warszawa \\ piotr.bajurko@ilot.edu.pl
}

\begin{abstract}
Carbon-epoxy composite materials, due to their high strength in relation to mass, are increasingly used in the construction of aircraft structures, however, they are susceptible to a number of damages. One of the most common is delamination, which is a serious problem in the context of safe operation of such structures. As part of the TEBUK project, the Institute of Aviation has developed a methodology for forecasting the propagation of delamination. In order to validate the proposed method, an aerial structure demonstrator, modelled on the horizontal stabilizer of the I-23 Manager aircraft, was carried out. However, in order to carry out the validation, it was necessary to "simplify" the demonstrator model. The paper presents a numerical analysis conducted in order to separate from the TEBUK demonstrator model a fragment of the structure, which was used to study the delamination area, as an equivalent of the whole demonstrator. Subcomponent selection was carried out in several stages, narrowing down the analysed area covering delamination in subsequent steps and verifying the compliance of specific parameters with the same parameters obtained in a full demonstrator model. The parameters compared were: energy release rate values on the delamination front line and strain values in the delamination area. The numerical analyses presented in the paper were performed with the use of the MSC.Marc/Mentat calculation package. As a result of the analyses, a fragment of the structure was selected, which allows to significantly reduce the time and labour consumption of the production of the studied object, as well as to facilitate experimental research.
\end{abstract}

Keywords: FEM, delamination, buckling, carbon-epoxy composite.

\section{INTRODUCTION}

Due to their high strength in relation to mass, layered composites with polymeric binders are increasingly used in many industries, in particular in the aerospace industry. Such composites, due to their layered structure and varied orientation of individual layers, show relatively low resistance to interlayer cracking $[1 \div 3]$. As a consequence, the most common disadvantage in composite materials is delamination caused mainly in the manufacturing process or during exploitation, e.g. as a result of 
low-energy impacts. Such damages constitute a serious problem in the context of safe operation of such structures $[4,5]$. If the presence of delamination is diagnosed in the structure of a composite, it is necessary to verify whether the given composite element qualifies for replacement, repair, or it can be left in its current state, if it does not pose a threat in further exploitation. Computer Aided Engineering (CAE) applications [6,7] based on the Finite Element Analysis (FEA) $[8 \div 10]$ are a helpful tool in assessing the risk of delamination propagation. The most popular FEA methods used to calculate delamination propagation are: VCCT (Virtual Crack Closure Technique) [11] and the method based on the Cohesive Zone model [12:14]. The VCCT method is based on the principles of linear fracture mechanics. This method requires prior definition of the delamination front in the model (i.e. indication of nodes at the beginning of delamination), which in some cases may be a serious limitation, e.g. when analyzing delamination caused by impact. The cohesion zone method combines, by means of failure mechanics, crack initiation criteria based on stress components with energy crack mechanics criteria [12]. This method requires prior placement of cohesive elements in the plane of expected delamination development. Currently available FEA programs provide algorithms that automatically insert cohesive elements between appropriate structural elements, e.g. on the basis of exceeding specific local stresses [15].

The scope of research works described in the article was carried out as part of the POIG TEBUK project "Development of technology for testing resistance to damage to aircraft and space composite load-bearing structures", carried out at the Institute of Aviation. The main objective of the project was to develop a model methodology for assessing the impact of damage on the durability and strength of structures made of modern composite materials. Within the framework of the project, a number of research works were carried out in order to develop numerical methods, which will allow for forecasting the possibility of delamination development. In order to verify experimental numerical analyses, a TEBUK damage demonstrator, designed on the basis of horizontal stabilizer of I-23 Manager aircraft $[16,17]$, was made and tested. The internal structure of the stabilizer was modified in order to provide conditions for research on structure damage development the description of modifications is contained in $[18,19]$. However, conducting experimental trials on a single unit proved to be insufficient, both in terms of statistical rules for conducting the experiment, as well as in terms of impossibility to investigate other cases of damage. Investigating a wider range of damage cases, and consequently a larger number of demonstrators, would require a very labour-intensive and costly manufacturing process, as well as significant amounts of material used for the construction of the research facility. In addition, it would require time-consuming preparation and experimental studies. In order to limit these factors, a "simplified" version of a demonstrator equivalent to a full structure was developed and executed [20].

The main objective of the work was to extract the subcomponent from the demonstrator model (the equivalent of the whole model) which will be used to study the delamination area. Subsequent versions of the subcomponent models were obtained by removing selected fragments from the base model (full demonstrator) and applying boundary conditions equivalent to the loads of the full model. As part of the numerical analyses carried out, four models of subcomponents were selected. The first model was tested in two load cases, i.e. under the influence of bending moment loads and axially compressive loads. Further models were considered only under compressive loads. Due to the extensive set of comparative results, the article briefly describes subsequent models, while comparative diagrams are presented only for the last version of the sub-component. It should be mentioned that the results from indirect models were very close to those obtained in the presented model. 


\section{RESEARCH OBJECT}

Figure 1 shows the initial shape and basic dimensions of the full demonstrator [18].

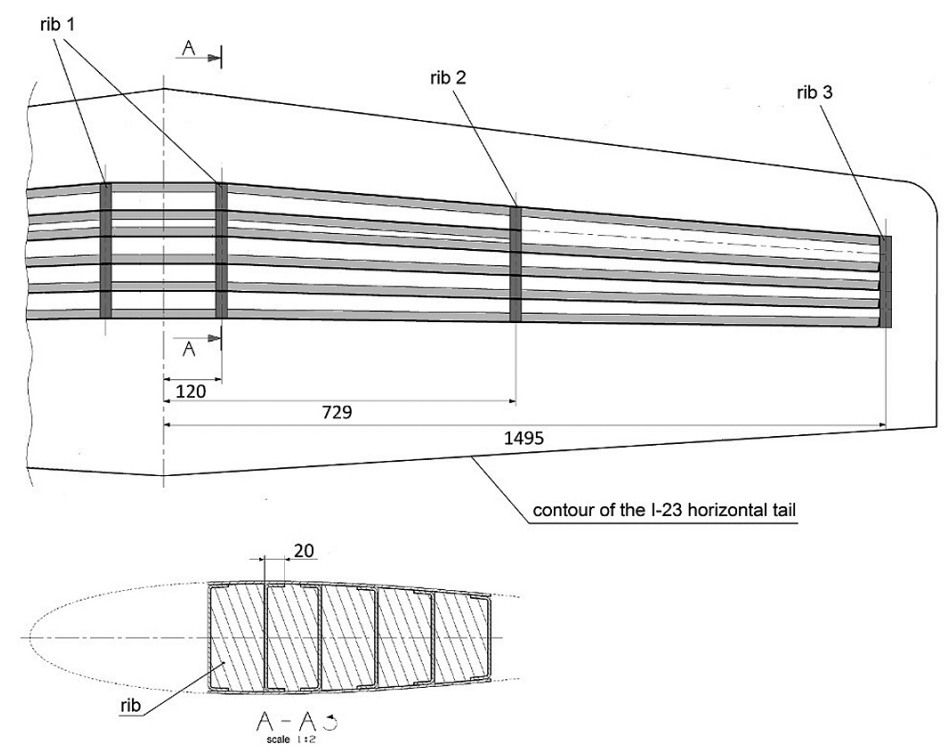

Fig. 1. Internal structure TEBUK project demonstrator in the contour of horizontal stabilizer of aircraft I-23 "Manager". [18]

Delamination with a diameter of $40 \mathrm{~mm}$ was placed exactly in the middle of the model between the third and fourth layer of the composite, counting from the surface of the mold. Preliminary delamination was obtained by placing a double teflon insert with a diameter of $40 \mathrm{~mm}$ and a thickness of $<0.013 \mathrm{~mm}$ during the manufacturing process. The centre of the delamination was 78 $\mathrm{mm}$ away from the external surface of the first wall.

For numerical modelling of the subcomponent a numerical model of the demonstrator was used, which was presented in previous works [21, 22] (Fig. 3), with the difference that the VCCT (Virtual Crack Closure Technique) method [11] was used for delamination analysis instead of cohesive elements [12]. This model was built of Shell type elements dedicated to the modeling of layered composites, marked as 75 and 138 according to MARC nomenclature, and Solid type elements marked as 185 [23]. The structure of the composite was modelled by defining the number of layers, arrangement of layers and their elastic properties in the properties of individual elements. The delamination area and its surroundings (square area of $100 \times 100 \mathrm{~mm}$ ) were modelled

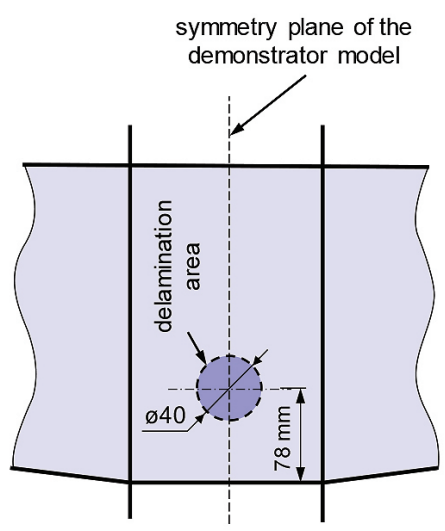

Fig. 2. Location of the delamination area relative to the full demonstrator model, [P. Bajurko, 2016]. with a regular grid of solid finite elements of $1 \times 1 \mathrm{~mm}$ size (Fig. 4 ), while the remaining fragments of the structure were modelled with Shell-type elements. 


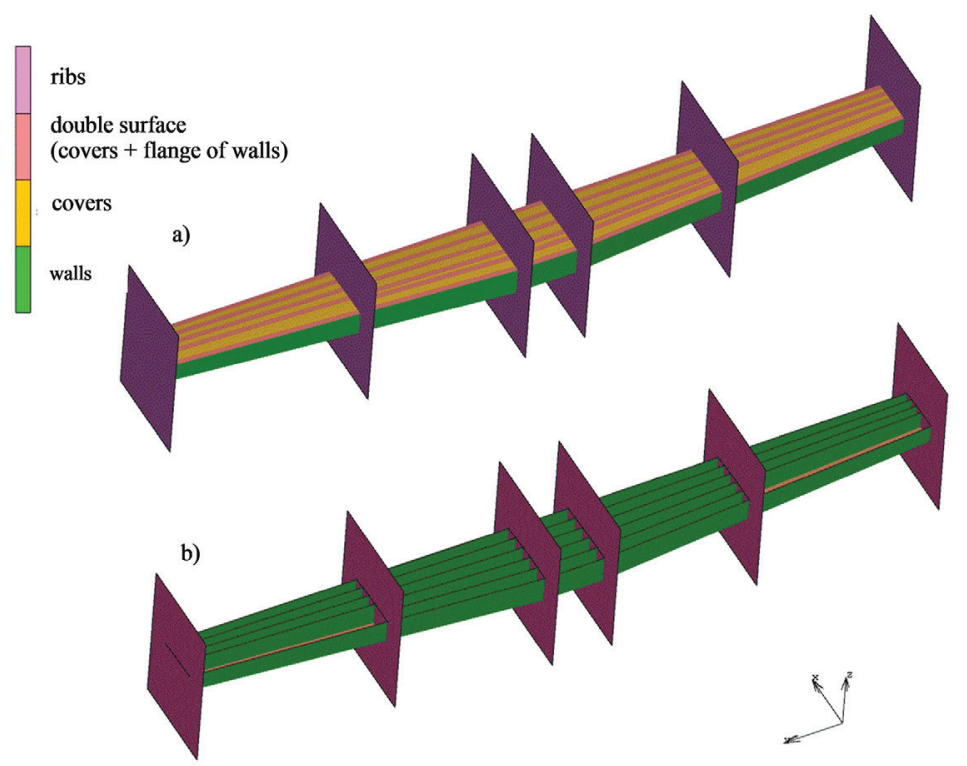

Fig. 3. Demonstrator's numerical model; a - general view, b - view of the internal structure of the demonstrator [P. Bajurko, 2015].

The areas of solid and shell elements were combined in such a way that the area of shell elements overlapped with the area of solid elements. In order to avoid stiffening of the structure at the joint site, the width of the joint was only one element $(1 \mathrm{~mm})$. In addition, in order to ensure that there

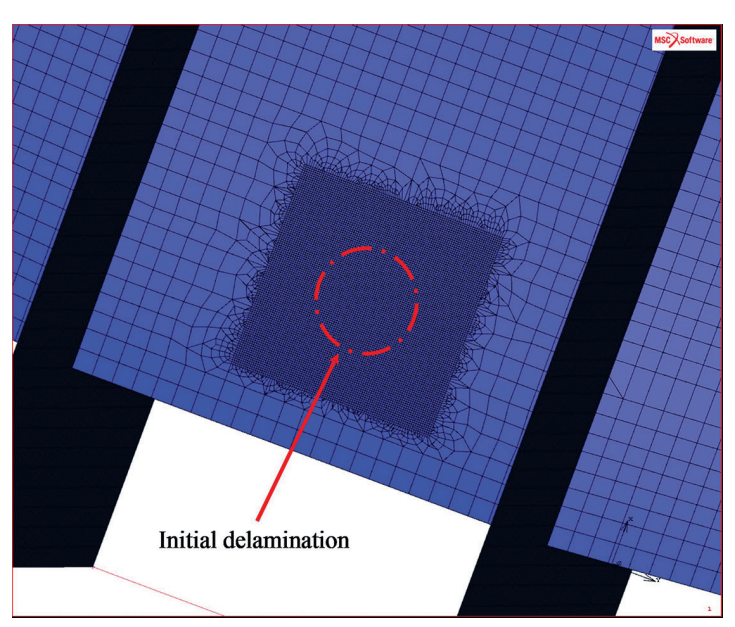

Fig. 4. Density of the finite element grid in the delamination area [P. Bajurko, 2015]. was no local stiffness of the structure at the joint, a verification was carried out on the basis of numerical results obtained from a model constructed entirely of shell elements. The density of the Shell mesh is about 10 times less than the density of solids. The density of the grid in the delamination area with respect to the rest of the model is dictated by the need to reproduce as accurately as possible the delamination behaviour during model loading. On the other hand, the use of a homogeneous grid was to minimize the impact of the grid shape on the development of delamination $[24 \div 26]$. The introduction of initial delamination in the numerical model was achieved by removing nodal connections of solid elements in the area corresponding to delamination. A numerical model was used for the study, in which the development of delamination was modelled with the use of the VCCT method, because it allows for direct reading of energy release rate values from individual nodes of the delamination front. In this method, the energy release rate $(G)$, characterizing the laminate resistance to interlaminar cracking, is calculated on the basis of forces and nodal displacements of the FEA model [11]. One of the simplest criteria for breaking the connection between nodes forming a front delamination of a form was used in the described analysis: 


$$
\frac{G_{I}}{G_{I c}}+\frac{G_{I I}}{G_{I I c}}+\frac{G_{I I I}}{G_{I I I c}}=1
$$

where: $G_{I}, G_{I I}$ and $G_{I I I}$ are energy release rates for the first, second and third cracking modes respectively, while $G_{I C}, G_{I I C}$ and $G_{I I I C}$ are critical energy release rates. The parameters used in the calculations are as follows: $G_{I C}=300 \mathrm{~N} / \mathrm{m}, G_{I I C}$ and $G_{I I C}=900 \mathrm{~N} / \mathrm{m}[24]$.

The elastic properties of the material used in the numerical model are the material data of the unidirectional carbon prepreg MTM46/HTS40(12K)-150gsm-35\%RW (lower and upper covers) and MTM46/CF0300-199gsm (walls) provided by the manufacturer - Advanced Composites Group (Table 1):

Tab. 1. Elastic properties of materials used in the numerical model

\begin{tabular}{|c|c|c|}
\hline Elastic properties & MTM46/HTS40(12K)-150gsm-35\%RW & MTM46/CF0300-199gsm \\
\hline$E_{11}, \mathrm{MPa}$ & 128290 & 59860 \\
\hline$E_{11}, \mathrm{MPa}$ & 8760 & 59860 \\
\hline$E_{11}, \mathrm{MPa}$ & 8760 & 8760 \\
\hline$v_{12}$ & 0.288 & 0.200 \\
\hline$v_{13}$ & 0.288 & 0.320 \\
\hline$v_{23}$ & 0.320 & 0.320 \\
\hline$G_{12}, \mathrm{MPa}$ & 4270 & 4170 \\
\hline$G_{13}, \mathrm{MPa}$ & 4270 & 3000 \\
\hline$G_{23}, \mathrm{MPa}$ & 3000 & 3000 \\
\hline
\end{tabular}

The system of covering structure layers is as follows $[0 / 90 / 0 / 90 / 0 / 0 / 45 /-45 /-45 / 45]_{s}$, while the system of wall structure layers: $[0 / 45 / 45 / 45 / 45]_{s}$ where the direction 0 is consistent with the demonstration span direction.

Figure 5 shows the loads and supports of a full demonstrator model - in this figure the model is shown in reverse orientation to show the points of deprivation of degrees of freedom $u_{x}, u_{y}$ and $u_{z}$. The loads in the form of eight concentrated forces correspond to one of the horizontal stabilizer load cases I-23 in flight [18]. In the following part of the article, the quoted loads will be treated as a nominal load - reference load.

Figure 6 shows the distribution of shear forces $T$, torsional moments $M_{s}$ and bending moments $M_{g}$ along the span of the whole demonstrator. In Figure 6 the force $F_{2}$ corresponds to the forces $F_{21}+F_{22}$, while the force $F_{3}$ corresponds to the forces $F_{31}+F_{32}$. 

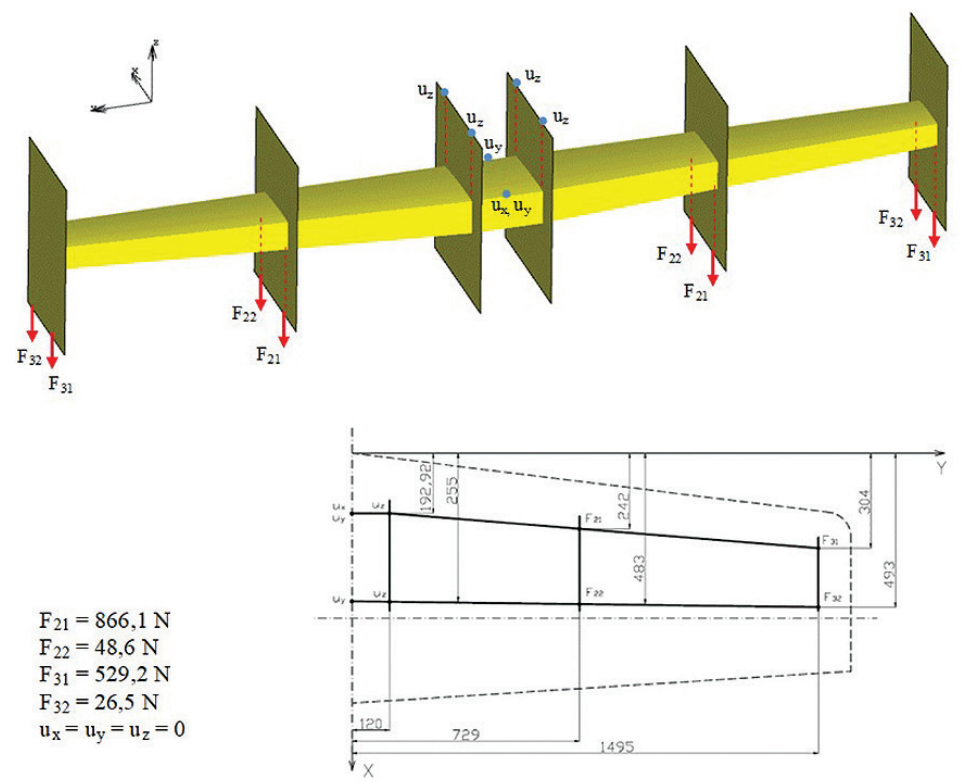

Fig. 5. Support conditions and nominal loads of the numerical model of the demonstrator [18].

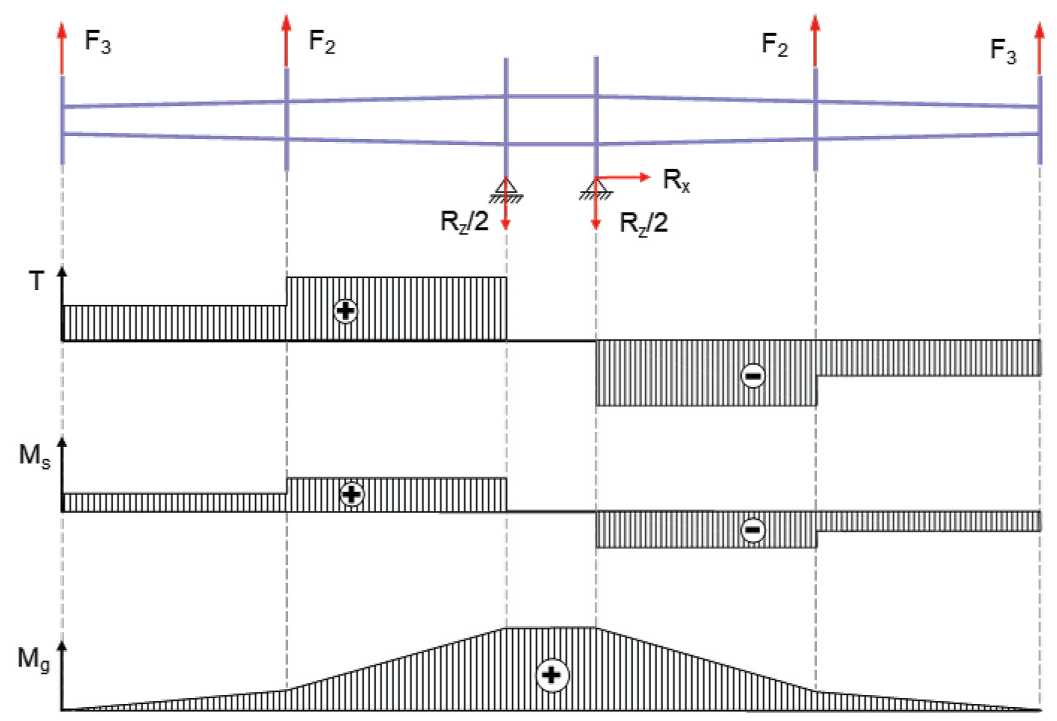

Fig. 6. Distribution of shear forces $T$, torsional moments $M_{s}$ and bending moments $M_{g}$ along the length of the demonstrator [P. Bajurko, 2015]. 


\section{SELECTION OF A SUBCOMPONENT}

Subsequent versions of subcomponent models were obtained by removing selected fragments from the base model (full demonstrator) and applying boundary conditions equivalent to the loads of the full model. Figure 6 shows that the demonstrator's research area (part of the demonstrator between ribs No. 1 - Fig. 1) is only loaded with bending moment. Therefore, as the first version of the subcomponent, a fragment of the demonstrator between the ribs was selected while the loads applied to ribs 2 and 3 of the full demonstrator were replaced with the equivalent bending moment $M_{g}$ (Fig. 7). Applying the bending moment $M_{g}$ to the model of the subcomponent causes the upper covering including delamination to be compressed. Considering this and the fact that applying the bending moment to the subcomponent is difficult to achieve on a real object, another simplification has been introduced - the bending moment has been replaced by a compressive force, as shown in Figure 8 .

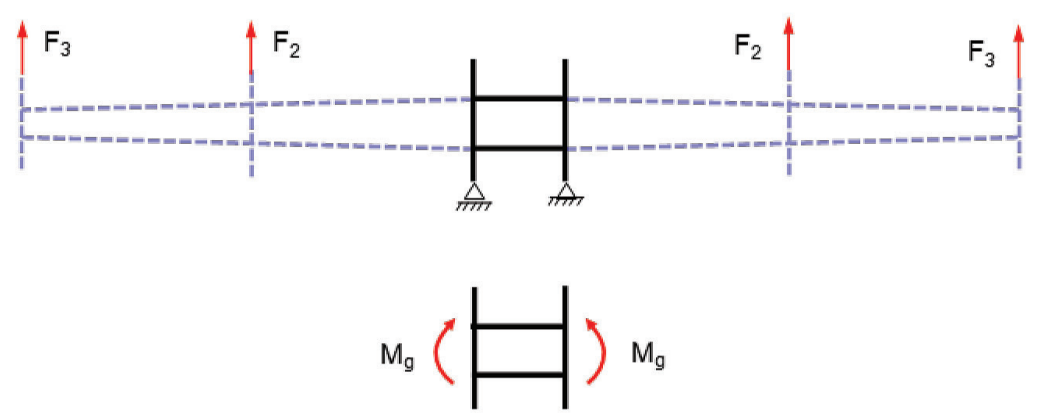

Fig. 7. Bending moment load of the subcomponent $M_{g}$ - equivalent of force pair $F_{2}$ and $F_{3}$ [P. Bajurko, 2015].

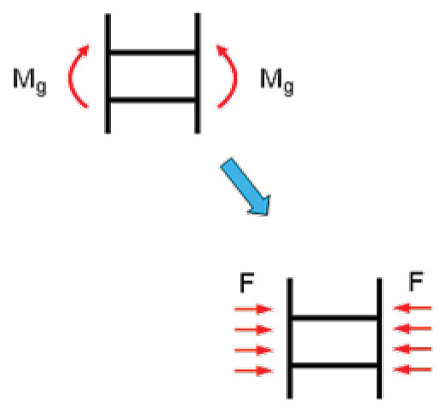

Fig. 8. Simplification by replacing the bending moment with a compressive force [P. Bajurko, 2015].

After such a change in load conditions, both the upper and lower cover of the subcomponent is compressed. Using this fact, it is possible to apply additional delamination in the lower cover of the actual subcomponent model, which will allow for testing two cases of delamination at the same time (in the upper and lower covers). In the further stages of searching for the optimal subcomponent, attempts were made to reduce the cross-section of the subcomponent, which determines the reduction of the compressive force. Subsequent versions of the subcomponents tested under compressive load conditions are presented in Table 2 (sections marked with a darker colour). Subsequent versions of the models were marked with $\mathrm{v} 1 \div \mathrm{v} 4$, respectively. 
Tab. 2. Cross-sections of subsequent versions of subcomponents

\begin{tabular}{|c|c|}
\hline & $\begin{array}{c}\text { Subsequent } \\
\text { versions of } \\
\text { subcomponents }\end{array}$ \\
\hline v1 & \\
\hline v2 & \\
\hline v3 & \\
\hline v4 & \\
\hline v5 & \\
\hline
\end{tabular}

\section{THE METHOD OF VERIFICATION OF SUBCOMPONENTS}

The main task of the subcomponent separated from the demonstrator's model is to obtain conditions for buckling and development of delamination identical to those prevailing in the full-scale demonstrator's model. Parameters that have a decisive influence on the development of delamination are the strains in the delamination area and the distribution of the energy release rate along the delamination front.

In order to compare the strains from the delamination area, 7 points were selected, which correspond to the points of sticking strain gauges $1 \div 7$ on the real demonstrator (Fig. 9). The selection of these points made it possible to compare them with the strains recorded during the experimental tests.

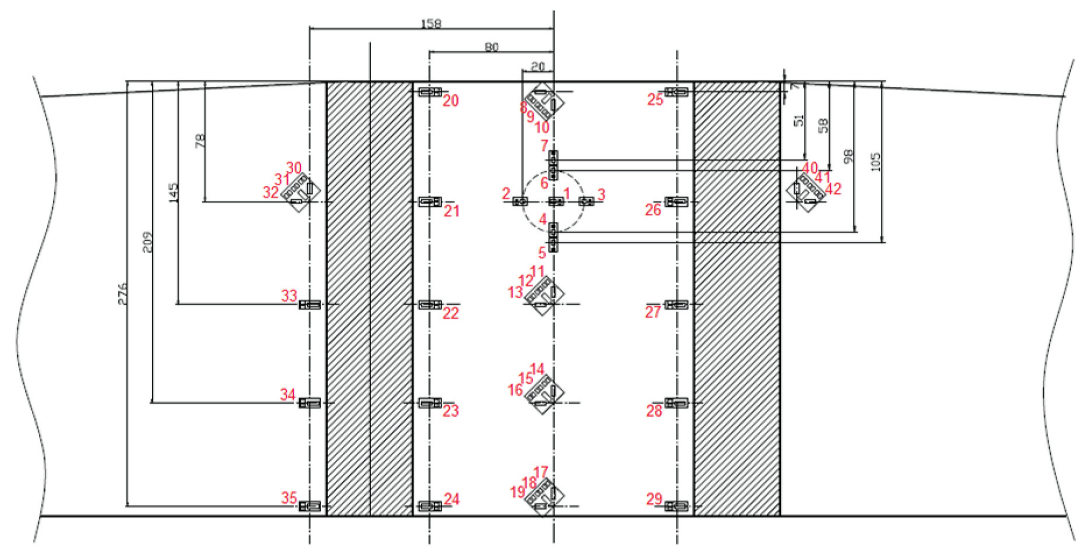

Fig. 9. Distribution of strain gauges on TEBUK demonstrator [4]. 
The load conditions applied in subsequent versions of the subcomponent, i.e. bending moment or compressive force, are equivalent to the load of the whole demonstrator, i.e. the sum of forces: $F_{21}, F_{22}$, $F_{31}$ and $F_{32}$ (Fig. 5). Therefore, in order to unify the presentation of results from individual subcomponents, the compared parameters are presented in the area of sum of forces: $F=F_{21}+F_{22}+F_{31}+F_{32}$. Conversion of subcomponent to demonstrator loads was carried out in the following way: the ratio of critical load (at which delamination stability loss occurs) of the whole demonstrator model to critical load of the subcomponent was calculated, and then the value of compressive force of the subcomponent was multiplied by the value of this ratio.

The second parameter compared to verify the results is the distribution of the energy release rate along the fracture face. Due to the symmetry of the model to be verified, only half of the delamination front was considered in the energy release rate. The length of the front was expressed in an angular scale, this angle was measured clockwise (Fig. 10).

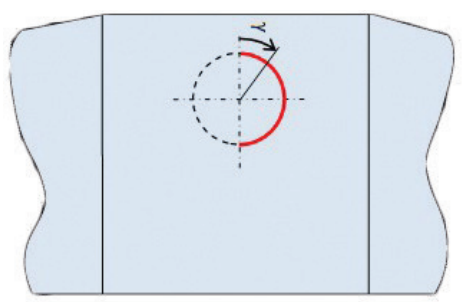

Fig. 10. Half of the delamination front for which the distribution of the energy release rate was determined [P. Bajurko, 2015].

\section{RESULTS}

Figures $11 \div 17$ show the strain variations as a function of nominal load for points corresponding to selected strain gauges $(1 \div 7)$. These diagrams show: data determined during demonstrator's experimental tests, data calculated on a full demonstrator's FEA model and data calculated on a subcomponent's FEA model. On each of the charts a picture was added, informing about the location of the strain gauge, which the given chart refers to.

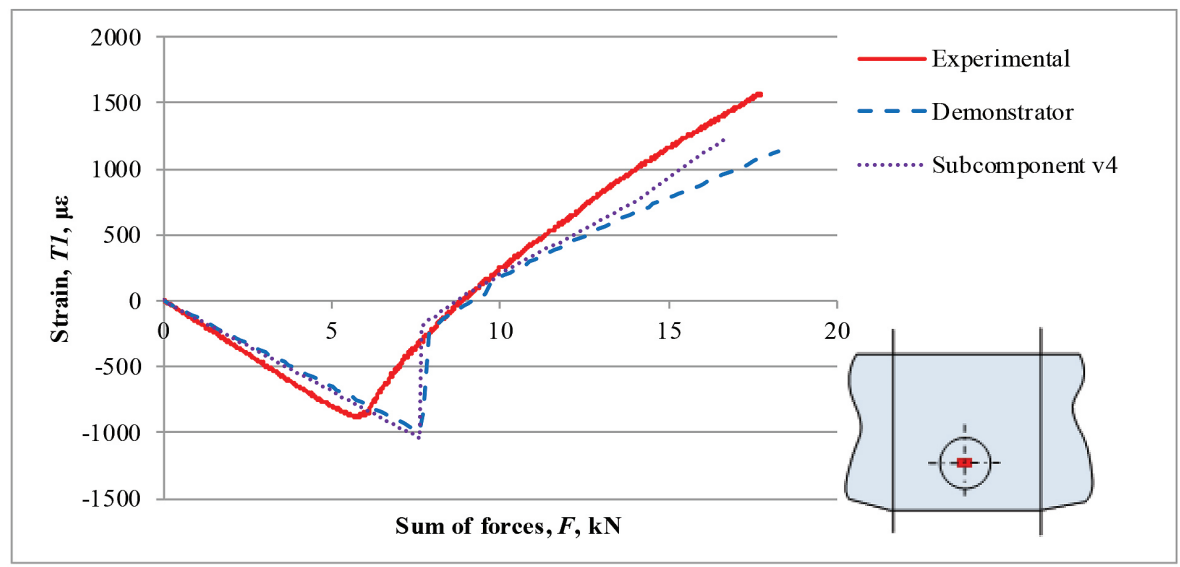

Fig. 11. Values of strain as a function of load at the point of the strain gauge 1. Measurement data and design data for the full demonstrator and subcomponent v4 loaded with compressive force [P. Bajurko, 2015]. 


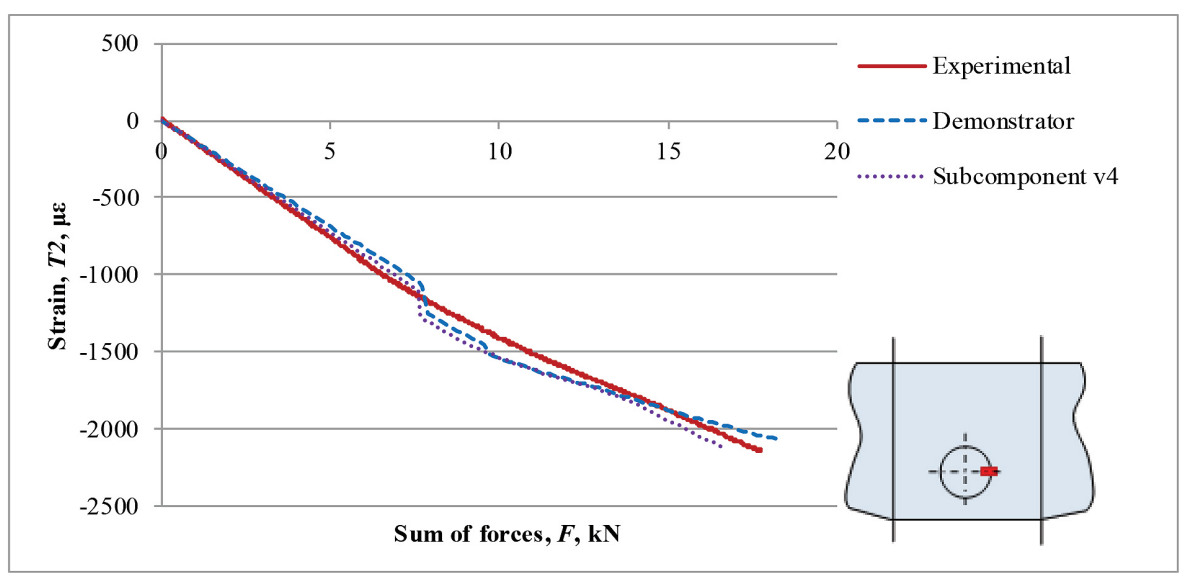

Fig. 12. Strain values as a function of load at strain gauge point 2, measurement data and design data for full demonstrator and subcomponent $\mathrm{v} 4$ loaded with compressive force [P. Bajurko, 2015].

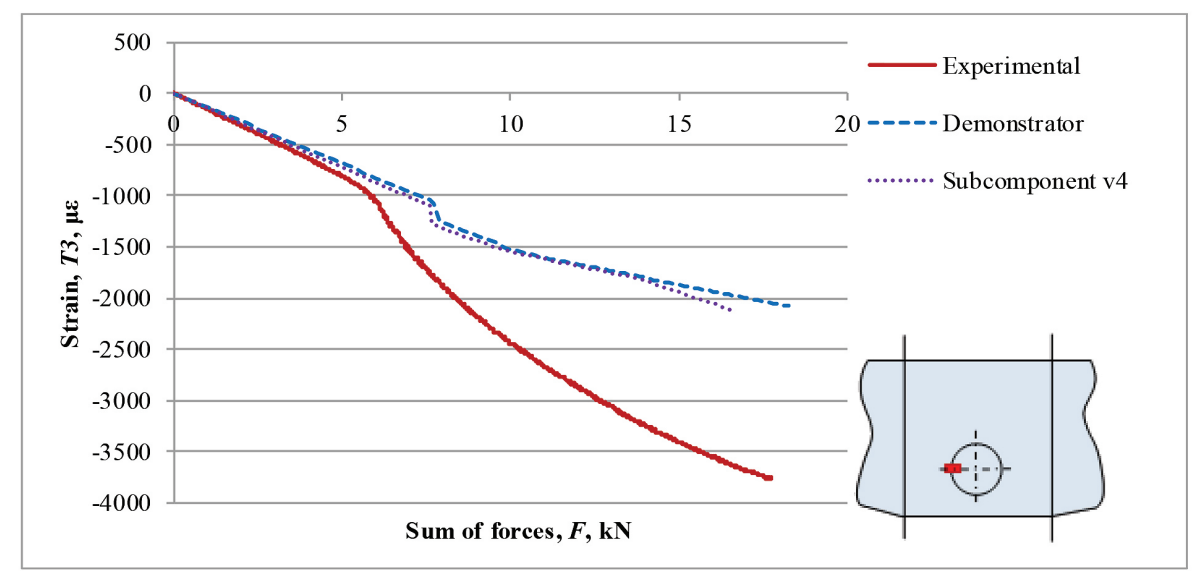

Fig. 13. Strain values as a function of load at strain gauge point 3, measurement data and design data for full demonstrator and subcomponent $v 4$ loaded with compressive force [P. Bajurko, 2015].

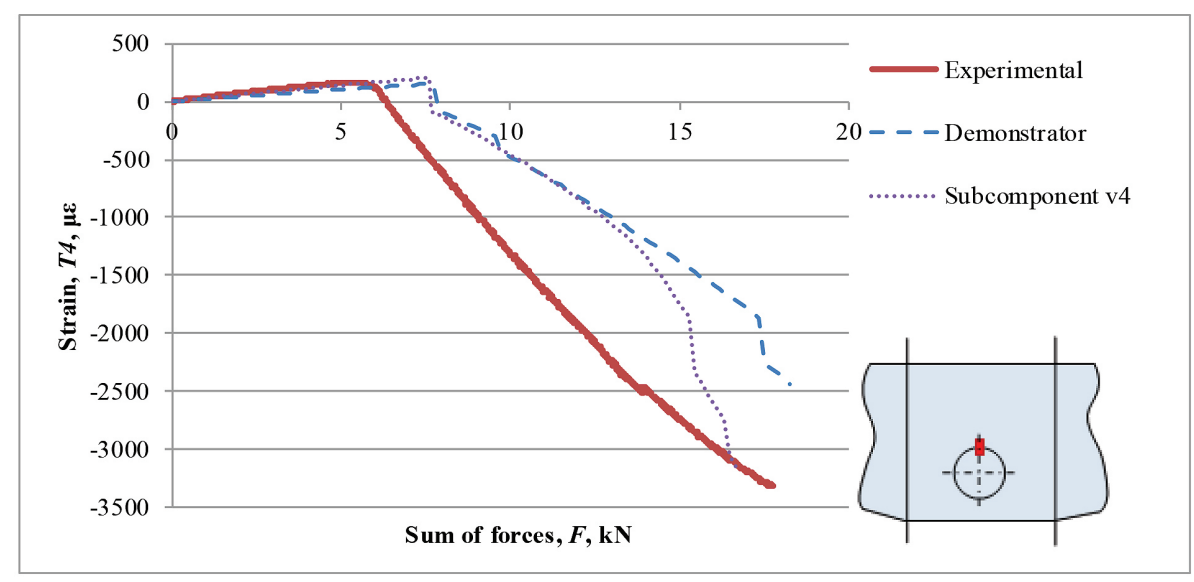

Fig. 14. Strain values as a function of load at strain gauge point 4, measurement data and design data for full demonstrator and subcomponent $\mathrm{v} 4$ loaded with compressive force [P. Bajurko, 2015]. 


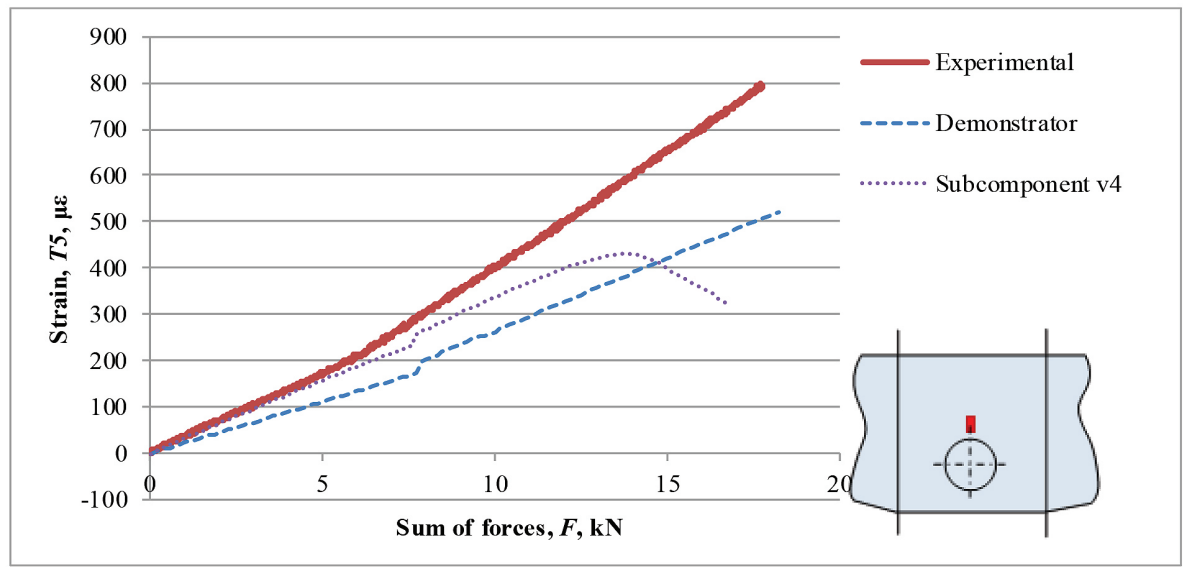

Fig. 15. Strain values as a function of load at strain gauge point 5, measurement data and design data for full demonstrator and subcomponent v4 loaded with compressive force [P. Bajurko, 2015].

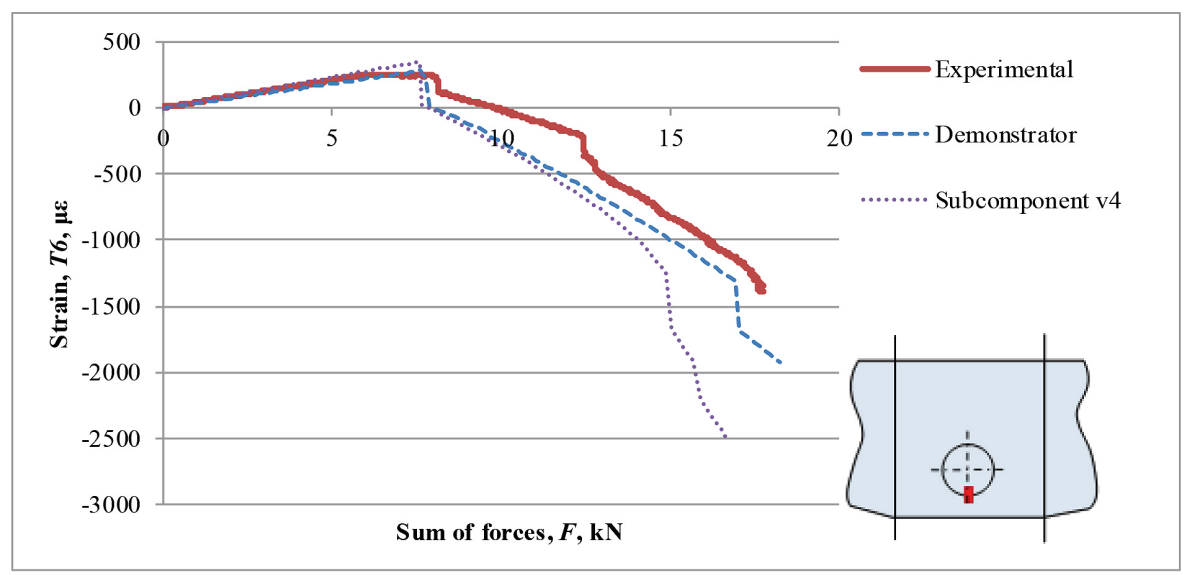

Fig. 16. Strain values as a function of load at strain gauge point 6 , measurement data and design data for full demonstrator and subcomponent v4 loaded with compressive force [P. Bajurko, 2015].

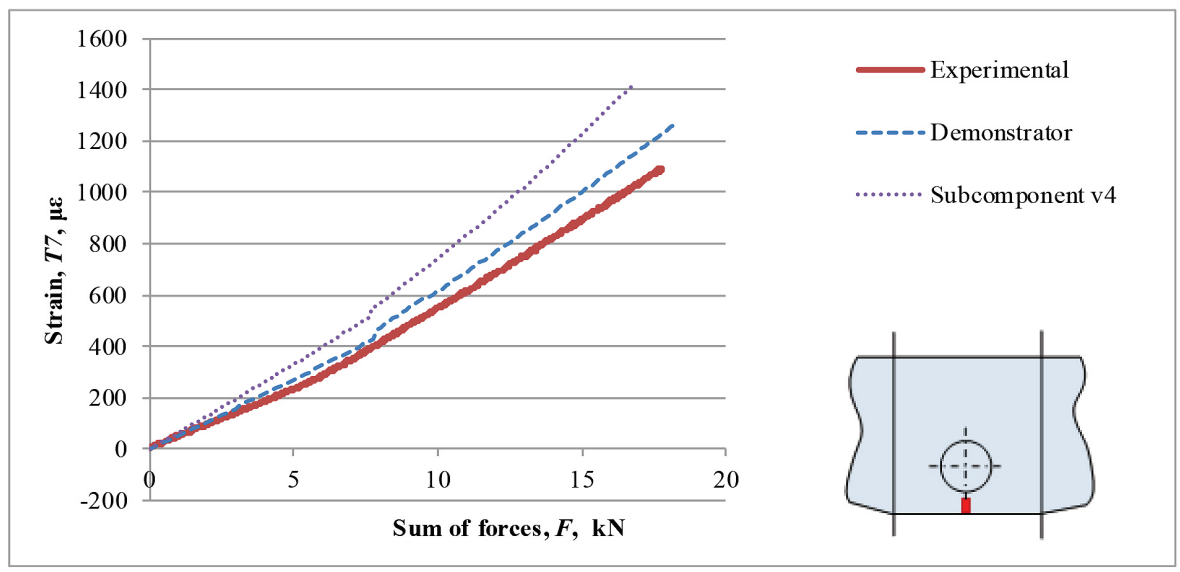

Fig. 17. Strain values as a function of load at strain gauge point 7 , measurement data and design data for full demonstrator and subcomponent $v 4$ loaded with compressive force [P. Bajurko, 2015]. 
The last two diagrams (Fig. $18 \div 19$ ) show the distribution of $G_{I}$ and $G_{I I}$ energy release rates along the delamination front. The third component of the energy release rate $G_{I I I}$ has a negligible contribution to the development of buckling delamination, therefore graphs of only the first two components of the energy release rate $G_{I}$ and $G_{I I}$ are presented. The presented diagrams (Fig. $18 \div 19$ ) correspond to the moment just before the beginning of delamination propagation.

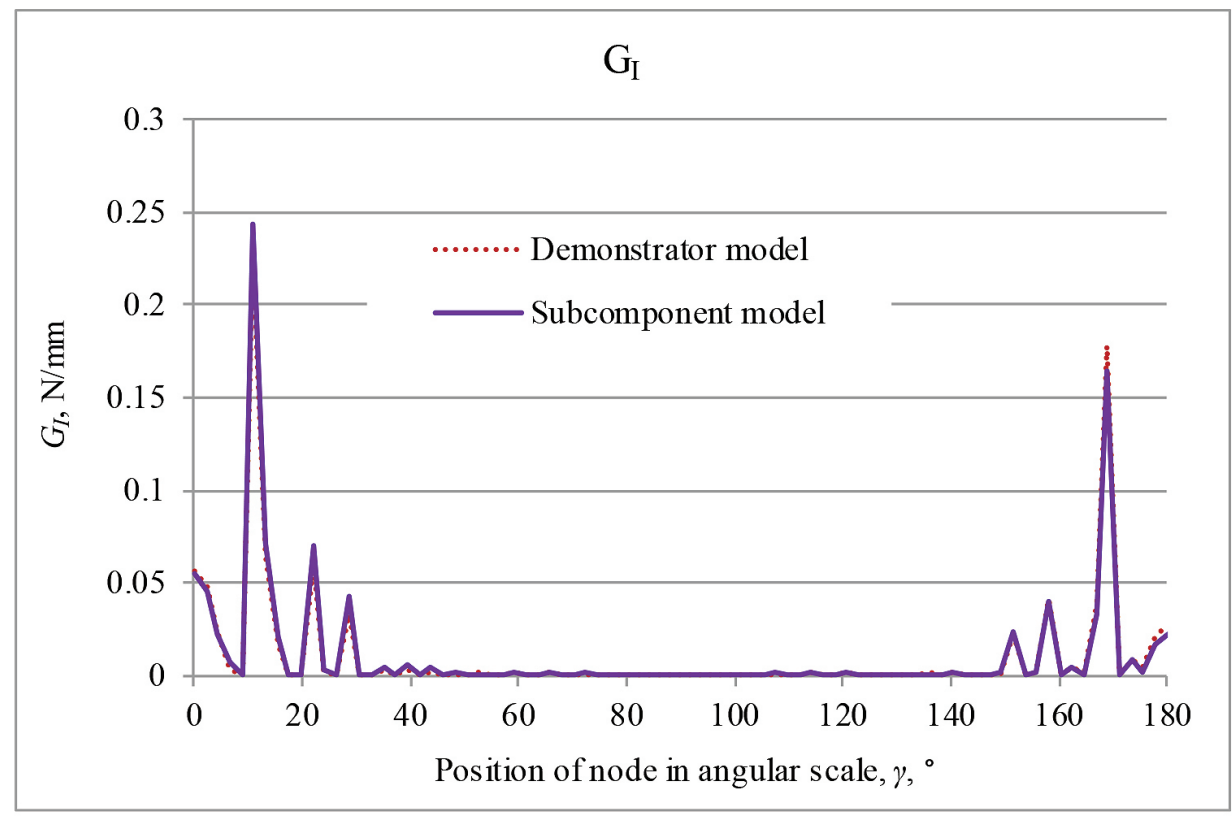

Fig. 18. $G_{I}$ distribution along the delamination front [P. Bajurko, 2015].

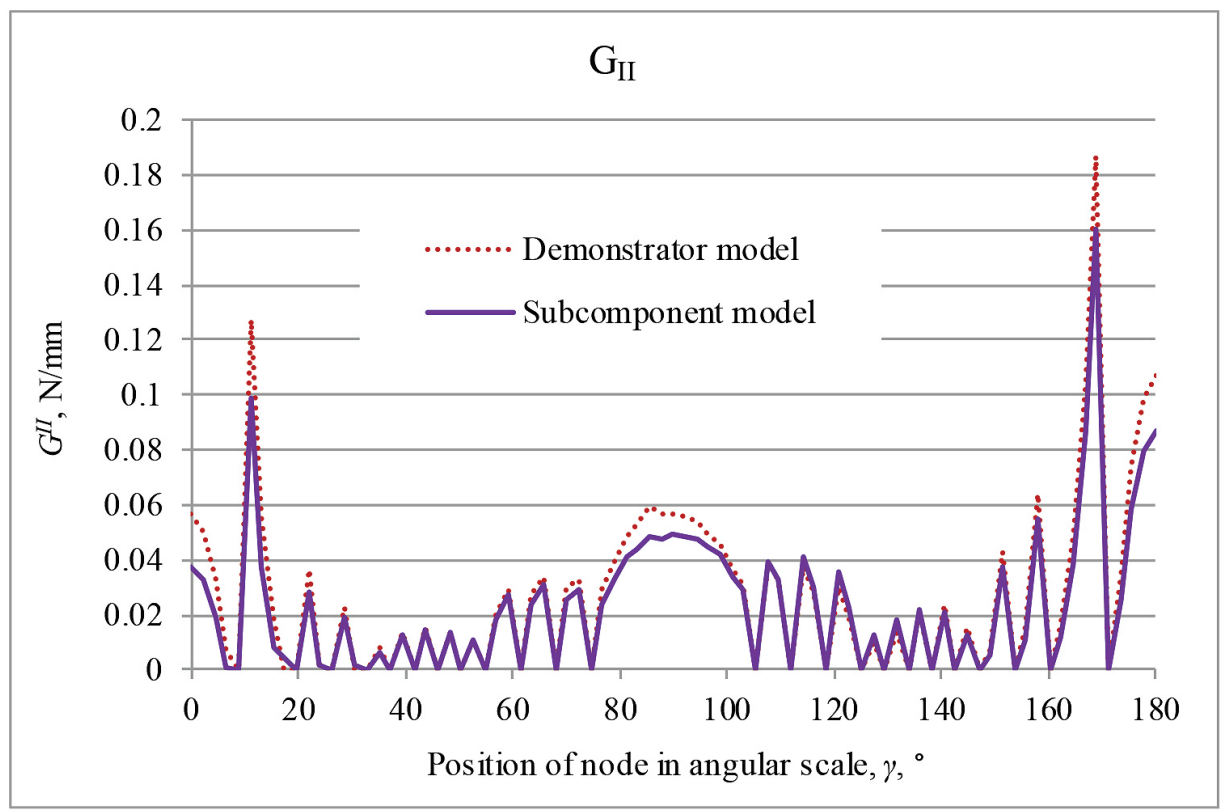

Fig. 19. Distribution of $G_{I I}$ along the delamination front [P. Bajurko, 2015]. 
Figure 20 shows the nodes of the initial delamination front and indicates the nodes that were broken due to the applied loads - the increase in delamination was observed only in four nodes. The observed development of delamination took place in the load range $10.5 \div 11.5$ times the nominal load. This was the case for all models of subcomponents and a full demonstrator. After reaching a compressive load of about $17 \mathrm{kN}$ (in the reference load scale), the numerical analysis was interrupted due to difficulties with the non-linear nature of calculations resulting in the lack of convergence of numerical calculations. This made it impossible to estimate whether delamination would promote under higher loads.

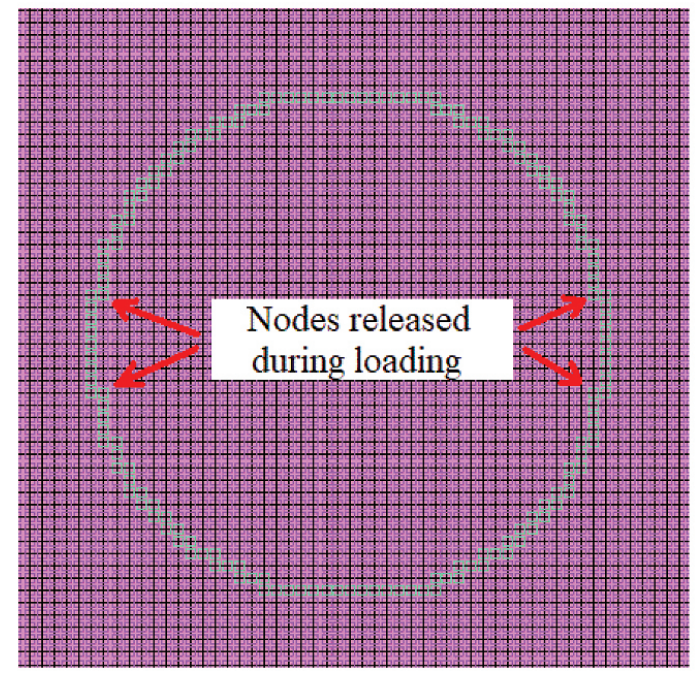

Fig. 20. The nodes of the initial delamination front and the nodes that were torn off during the model load increase [P. Bajurko, 2015].

\section{CONCLUSIONS}

The results of the research carried out allow the following conclusions to be drawn:

1. Comparison of the compressive strain - compressive load at strain gauge 1 at the centre of delamination (Fig. 11) shows that the experimentally determined buckling moment of sub-laminates separated by delaminations occurs slightly earlier than the numerically determined moment $(F=6 \mathrm{kN}$ for the experimental model and $F=7.5 \mathrm{kN}$ for FEA models). This discrepancy may result from the fact that the measuring system had a certain stiffness resulting from the finite accuracy of the demonstrator's workmanship, the quality of composite components (walls and covers), as well as the quality of the bond between the glued walls and the covers, while the numerical model reflected the ideal case.

2. On the graphs showing strains at points corresponding to strain gauges 3,4 , and 5 , differences in the intensity of changes in strains determined experimentally and numerically (in the FEA model) were observed. These discrepancies may be due to the fact that the position of delamination in the demonstrator was estimated on the basis of ultrasonic inspection with an accuracy of about $1 \mathrm{~mm}$. This could have led to a situation where strain gauges, which were to be located above or adjacent to the delamination front line, were glued over or adjacent to the delamination area, and consequently showed overstated results.

3. The results of the energy release rate analysis show that the distribution of the $G_{I}$ component along the delamination front of the subcomponent model coincides with the $G_{I}$ recorded in the full demonstrator model. The $G_{I I}$ components of the subcomponent are slightly smaller than in a full demonstrator model. However, in places where delamination is expected to develop, the $G_{I}$ component will have a decisive influence on the possibility of delamination development. Therefore, it can be considered that the conditions for the development of delamination of the subcomponent model in terms of the energy release rate will be the same as the conditions that exist in the whole demonstrator model.

4. The beginning of the development of delamination for all sub-component and full demonstrator models took place in the load range of $10.5 \div 11.5$ times the nominal load, which proves the acceptable convergence of numerical models. 
5. The graphs of strains show that the strains recorded on the demonstrator model coincide with the strains of the subcomponent model. The obtained repeatability of the results indicates the conformity of the strain field in these models, as well as repetitive conditions of delamination development. The numerical model of the demonstrator can be replaced by a subcomponent model without any qualitative or quantitative losses of the obtained results. Only the strains of the subcomponent $\mathrm{v} 4$ at the point of strain gauge 5 after exceeding the compressive loads, corresponding to the sum of forces of $15 \mathrm{kN}$, start to differ significantly from the strains of the demonstrator's model. The differences in strain observed are due to the fact that the unsupported parts of the cladding in the v4 model are corrugated/deformed under compressive loads. This is illustrated in Figure 21, where Figure 21a shows the displacements in the $\mathrm{Z}$ direction of the model of subcomponent $\mathrm{v} 4$ and Figure $21 \mathrm{~b}$ shows the displacements in the $\mathrm{Z}$ direction of model v3.

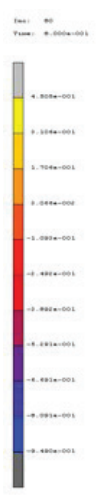

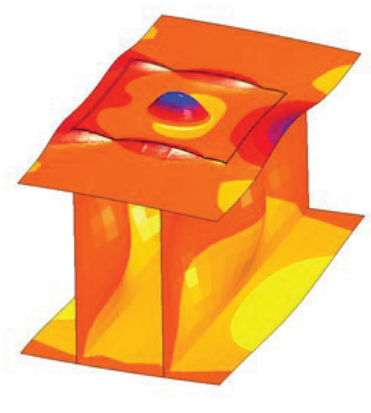

(...................
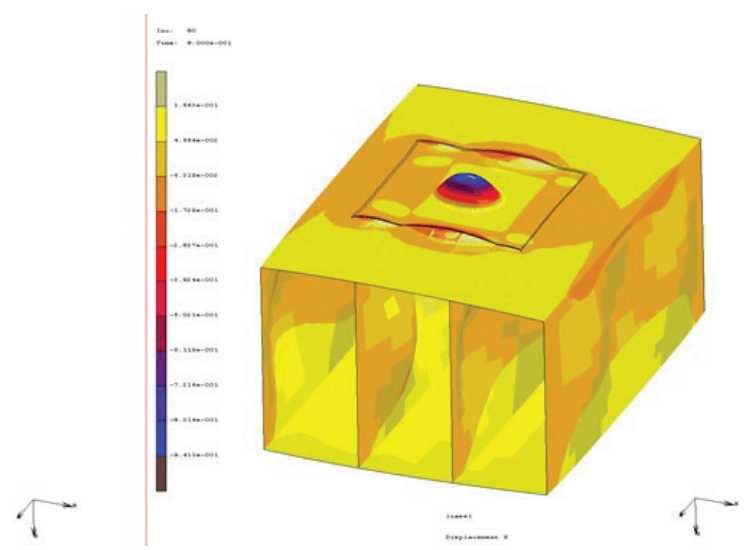

Fig. 20. Comparison of strains: a - subcomponent v4, b - subcomponent v3 [P. Bajurko, 2015].

The observed buckling of the cover layers may affect the delamination development potential. Due to the fact that in earlier models $\mathrm{v} 1, \mathrm{v} 2$ and $\mathrm{v} 3$ this problem did not occur, model $\mathrm{v} 3$ is the recommended subcomponent for experimental studies. Alternatively, the choice of model v 4 should take into account additional stiffening to prevent buckling of the free edges of the covers.

6. Due to the demonstrator replacement with a subcomponent, it is possible to limit the amount of material used for the construction of the research facility. Moreover, reducing the size of the object under study also allows to minimize the time and labour-consumption of the production of the object under study and to conduct the research.

The research presented in the publication was carried out as part of the TEBUK project "Development of technologies for testing resistance to damage to aerospace composite load-bearing structures" POIG.01.01.02-14-017. The project was financed by the European Regional Development Fund within the Innovative Economy - National Cohesion Strategy Programme. 


\section{REFERENCES}

[1] Heslehurst, R. B.,2014, Defects and Damage in Composite Materials and Structures, CRC Press.

[2] Deborah D.L.C., 2010, Composite Materials, Science and Applications, 2nd Edition, Springer, New York, London.

[3] Barbero E.J., 2010, Introduction to composite material design, Taylor \& Francis.

[4] Epaarachchi, J.A., Kahandawa, G.C., 2016, Structural Health Monitoring Technologies and Next-Generation Smart Composite Structures, CRC Press.

[5] Tomblin, J., Seneviratne, W., 2011, Determining the Fatigue Life of Composite Aircraft Structures Using Life and Load-Enhancement Factors, Air Traffic Organization NextGen \& Operations Planning Office of Research and Technology Development Washington, DC 20591.

[6] Chlebus, E., 2000, Techniki komputerowe CAx w inżynierii produkcji. Wydawnictwa Naukowo-Techniczne.

[7] Sarkar, J., 2017, Computer Aided Design: A Conceptual Approach, CRC Press.

[8] Rakowski, G., Kacprzyk, Z., 2005, Metoda elementów skończonych w mechanice konstrukcji, Oficyna Wydawnicza Politechniki Warszawskiej, Warszawa.

[9] Akin J.E., 1982, Application and the implementation of finite element methods, Academic Press, New York.

[10] Rugarli, P., 2010, Structural Analysis with Finite Elements, Thomas Telford.

[11] Krueger, R., 2004, „Virtual crack closure technique: History, approach, and applications,” Appl. Mech., 57(2), pp. 109-143.

[12] Dobrzański, P., 2016, „Modelowanie strefy kohezyjnej”, Prace Instytutu Lotnictwa, 2(243). s. $170-186$.

[13] Allix, O., Ladeveze, P., 1992, Interlaminar interface modelling for the prediction of delamination. Composite Structures, 22(4):235-242, 1992.

[14] Alfano, G.,Crisfield, M.A., 2001, Finite element interface models for the delamination analysis of laminated composites: mechanical and computational issues. International Journal for Numerical Methods in Engineering, 50(7):1701-1736.

[15] 2014, „Marc user's Manual, Volume A: Theory and User Information”.

[16] Królikiewicz, T., 2006, „Samoloty i śmigłowce Instytutu Lotnictwa. Samoloty dyspozycyjne. Ostatnie projekty.”. Lotnictwo nr 5.

[17] Wiśniowski, W., 2014, "XX lat Programu Samolotów Lekkich I Bezpieczeństwa (PSLIB)", Prace Instytutu Lotnictwa 3(236). s. 7-25.

[18] Osmęda, A., 2012, Analiza wytrzymałościowo-konstrukcyjna demonstratora, Raport wewnętrzny, 05/BU/2012/TEBUK, Instytut Lotnictwa, Warszawa.

[19] Osmęda, A., 2016, "Porównanie wyników analiz numerycznych i prób wytrzymałościowych demonstratora struktury lotniczej”, Prace Instytutu Lotnictwa, 3(244). s. 123-134.

[20] Bajurko, P., 2015, Modelowanie subkomponentu demonstratora TEBUK, Raport wewnętrzny 68/LK/2015/TEBUK, Instytut Lotnictwa, Warszawa.

[21] Bajurko, P., 2013, „Liniowa analiza wyboczeniowa demonstratora TEBUK”, Raport wewnętrzny, 12/BU/2013/TEBUK, Instytut Lotnictwa, Warszawa. 
[22] Bajurko, P., 2013, „Obliczeniowa analiza wytrzymałości statycznej demonstratora TEBUK”, Raport wewnętrzny 17/BU/2013/TEBUK, Instytut Lotnictwa, Warszawa.

[23] 2014, „Marc user's Manual, Volume B: Element Library”

[24] Bajurko, P., Wilk, J., Szeląg, D., and Czarnocki, P., 2014, "Numerical modeling of delamination growth in composite plates," Shell Structures, Theory and Applications, CRS Press, Gdańsk, pp. 373-376.

[25] Bajurko, P., and Czarnocki, P., 2014, "Numerical and experimental investigations of embedded delamination growth caused by compressive loading," Journal of Theoretical and Applied Mechanics, 52(2), pp. 301-312.

[26] Wilk, J., 2015, "Assessing the hazard of delamination propagation in composites using numerical analysis," Composites Theory and Practice, R. 15, nr 1, pp. 34-38.

\section{MODELOWANIE SUBKOMPONENTU DEMONSTRATORA STRUKTURY LOTNICZEJ}

\section{Streszczenie}

Węglowo-epoksydowe materiały kompozytowe ze względu na ich wysoką wytrzymałość w stosunku do masy są coraz częściej wykorzystywane do budowy struktur lotniczych, są jednak podatne na szereg uszkodzeń. Jednym z najczęściej spotykanych jest delaminacja, która stanowi poważny problemem w kontekście bezpieczeństwa eksploatacji takich struktur. W Instytucie Lotnictwa w ramach projektu TEBUK opracowano metodykę, pozwalającą prognozować propagację rozwarstwień. W celu walidacji zaproponowanej metody wykonano demonstrator struktury lotniczej, wzorowany na stateczniku poziomym samolotu I-23 Manager. Jednak do wykonania walidacji niezbędne okazało się „uproszczenie” modelu demonstratora. W artykule przedstawiono analizę numeryczną, przeprowadzoną w celu wyodrębnienia z modelu demonstratora TEBUK fragmentu struktury, który wykorzystano do badania obszaru delaminacji, jako ekwiwalent całego demonstratora. Wytypowanie subkomponentu przeprowadzono w kilku etapach, zawężając w kolejnych krokach analizowany obszar obejmujący delaminację i weryfikując zgodność określonych parametrów z tożsamymi parametrami uzyskanymi w modelu pełnego demonstratora. Porównywanymi parametrami były: wartości współczynnika uwalniania energii (WUE) na linii frontu delaminacji oraz wartości odkształceń w obszarze delaminacji. Prezentowane w pracy analizy numeryczne wykonano za pomoca pakietu obliczeniowego MSC.Marc/Mentat. W rezultacie przeprowadzonych analiz wytypowano fragment struktury pozwalający w znacznym stopniu ograniczyć czasochłonność i pracochłonność wytwarzania badanego obiektu, a także ułatwić przeprowadzenie badań eksperymentalnych.

Słowa kluczowe: MES, delaminacja, wyboczenie, kompozyt węglowo-epoksydowy. 